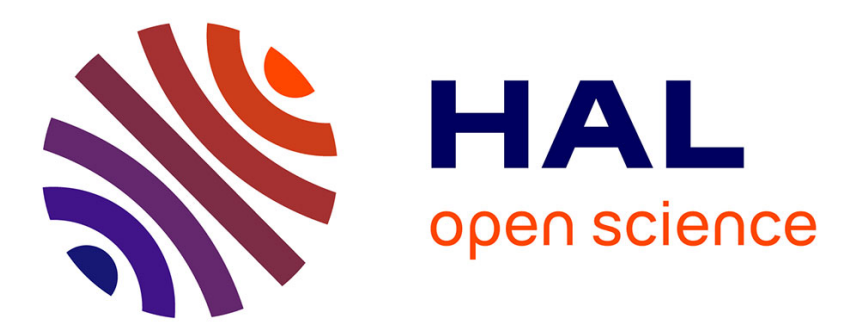

\title{
Seasonal changes in odour preferences by male euglossine bees (Hymenoptera: Apidae) and their ecological implications
}

\author{
Stefan Abrahamczyk, Peter Gottleuber, Michael Kessler
}

\section{To cite this version:}

Stefan Abrahamczyk, Peter Gottleuber, Michael Kessler. Seasonal changes in odour preferences by male euglossine bees (Hymenoptera: Apidae) and their ecological implications. Apidologie, 2012, 43 (2), pp.212-217. 10.1007/s13592-011-0096-7 . hal-01003636

\section{HAL Id: hal-01003636 https://hal.science/hal-01003636}

Submitted on 1 Jan 2012

HAL is a multi-disciplinary open access archive for the deposit and dissemination of scientific research documents, whether they are published or not. The documents may come from teaching and research institutions in France or abroad, or from public or private research centers.
L'archive ouverte pluridisciplinaire $\mathbf{H A L}$, est destinée au dépôt et à la diffusion de documents scientifiques de niveau recherche, publiés ou non, émanant des établissements d'enseignement et de recherche français ou étrangers, des laboratoires publics ou privés. 


\title{
Seasonal changes in odour preferences by male euglossine bees (Hymenoptera: Apidae) and their ecological implications
}

\author{
Stefan AbrahamczyK ${ }^{1}$, Peter GotTleuber ${ }^{2}$, Michael Kessler ${ }^{1}$ \\ ${ }^{1}$ Institute for Systematic Botany, University of Zurich, Zollikerstrasse 107, 8008 Zurich, Switzerland \\ ${ }^{2}$ Department of Systematic Botany, University of Goettingen, Untere Karspuele 2, 37073 Goettingen, Germany
}

Received 25 February 2011 - Revised 21 June 2011 - Accepted 16 September 2011

\begin{abstract}
Orchid bees are an important group of specialized insect pollinators in the Neotropics. Male orchid bees are attracted by a wide range of aromatic substances often produced by flowers. Previous studies found that in some species the males change their aromatic preferences between seasons. In our study we documented seasonal changes of aromatic preferences in five euglossine bee assemblages along a 380-km-long seasonality and precipitation gradient and related them to climatic factors. We found that the proportion of species per site showing changes in their aromatic preference between seasons increased with climatic seasonality towards the south. Those species mainly belong to the genus Euglossa, subgenus Euglossa. We conclude that climatic seasonality mainly affects the orchid bees via the turnover of the aromatic substances provided by the plants. Further, we suggest that the ability to change the aromatic preference between seasons could be interpreted as a phylogenetic pre-adaptation that enabled some species to colonize climatically strongly seasonal habitats.
\end{abstract}

climatic gradient / precipitation / temperature / distribution / generalist

\section{INTRODUCTION}

The about 200 species of euglossine orchid bees are an important group of insect pollinators in the Neotropics. A wide range of plant species from numerous families are visited by male and female orchid bees in order to feed on nectar or by males to collect aromatic substances (Ramírez et al. 2010a). Up to 650 orchid species exclusively produce fatty, aromatic substances as floral reward and exclusively rely on the pollination

Electronic supplementary material The online version of this article (doi:10.1007/s13592-011-0096-7) contains supplementary material, which is available to authorized users.

Corresponding author: S. Abrahamczyk, abraha@systbot.uzh.ch

Manuscript Editor: Bernd Grünewald by male orchid bees (Whitten and Williams 1991). Male orchid bees collect aromatic substances mainly from floral sources and store them in pockets of their enlarged hind tibias where they mix a perfume to attract females for mating (Ramírez et al. 2010b).

Overall, orchid bees collect a wide range of different aromatic substances (Ackerman 1989). Some species are attracted by many substances, while others are specialized to one or a few. Eltz et al. (2005) showed that the composition of aromatic substances orchid bees collect is species specific and not influenced by locality or habitat on a local to regional scale. But it can change between seasons. In every orchid bee assemblage studied to date over a longer time period, some orchid bee species, usually those that are attracted by a large number of aromatic substances, change their aromatic preferences 
between seasons (Pearson and Dressler 1985; Ackerman 1989), but the reasons for these preference changes remain unknown. Ackerman (1989) and Ramírez et al. (2010b) further reported large-scale, geographical variations of preferences for aromatic substances between orchid bee populations of the same species, but the variations between populations were not related to environmental factors. Ackermann (1989) thus speculated that the environmental components involved are related to season, geography, fragrance availability, and population age. He included population age because Zimmermann and Madrinan (1988) showed that bee age may have a substantial influence on the fragrance foraging activity of male euglossine bees. Eltz et al. (1999, 2005) showed that especially older male orchid bees learn how much of a substance they have already collected and start to avoid it after a while. Additionally, the strength of climatic seasonality, in both temperature or precipitation, may also be expected to relate to seasonal shifts in foraging preferences among bees, but this factor has not yet been considered in detail.

In our study we focussed on the influence of climatic seasonality on the proportion of orchid bee species that change their aromatic preferences between seasons. We asked the following questions:

1. Which climatic factor is most closely related to the proportion of species in an assemblage that change their aromatic preferences between seasons?

2. What potential advantages might there be in the ability of orchid bee species to change their aromatic preference between seasons?

\section{MATERIALS AND METHODS}

\subsection{Study sites}

We sampled orchid bees between November 2007 and October 2008 at five sites along a 380-km-long latitudinal gradient from tropical, evergreen rainforests in central Bolivia (Villa Tunari: 16 $6^{\circ} 57^{\prime} 59 \mathrm{~S}$, $65^{\circ} 24^{\prime} 44$ W; Sacta: $17^{\circ} 06^{\prime} 03 \mathrm{~S}, 64^{\circ} 47^{\prime} 02 \mathrm{~W}$; Buena Vista: $17^{\circ} 30^{\prime} 49 \mathrm{~S}, 63^{\circ} 38^{\prime} 16 \mathrm{~W}$ ) to subtropical, deciduous dry forests in southern Bolivia (Santa Cruz: $17^{\circ} 46^{\prime} 48 \mathrm{~S}, 63^{\circ} 04^{\prime} 02 \mathrm{~W}$; Río Seco: $18^{\circ} 42^{\prime}$ $\left.44 \mathrm{~S}, 63^{\circ} 11^{\prime} 35 \mathrm{~W}\right)$. Study sites were located in primary, lowland forests at 200-440 ma.s.1., which are part of a larger forest system extending from Amazonia to the Gran Chaco. At each locality, we established a $1-\mathrm{km}$ transect inside the forest and a shorter 350-m transect at the forest edge. We visited each site twice, once in the rainy (November to April) and once in the dry (May to October) season. Sampling was conducted for 4 days per site and season. Climate data were extracted from WorldClim (Hijmans et al. 2005; Table I).

\subsection{Census techniques}

Euglossine bees were baited with the eight most powerful attractants following Ackerman (1983c): 18 cineole, benzyl acetate, methyl benzoate, eugenol, methyl salicylate, methyl cinnamate, vanillin, and additionally, the commercial drugs Olbas and Gelomyrtol as well as hydrogendiethylester and tea-tree oil. To catch the orchid bees, self-made modified McPhail traps were used (Steyskal 1977). All traps were placed about 15 paces apart and $1.7 \mathrm{~m}$ above ground in a straight line. Additionally, from 7:30 a.m.

Table I. Environmental data of the study sites as extracted from WorldClim (Hijmans et al. 2005); temperature seasonality (standard deviation *100), precipitation seasonality (coefficient of variation).

\begin{tabular}{lccccc}
\hline & $\begin{array}{l}\text { Mean temperature } \\
\left({ }^{\circ} \mathrm{C}\right)\end{array}$ & $\begin{array}{l}\text { Min. temperature } \\
\left({ }^{\circ} \mathrm{C}\right)\end{array}$ & $\begin{array}{l}\text { Temperature } \\
\text { seasonality }\end{array}$ & $\begin{array}{l}\text { Mean precipitation } \\
(\mathrm{mm})\end{array}$ & $\begin{array}{l}\text { Precipitation } \\
\text { seasonality }\end{array}$ \\
\hline Río Seco & 24.30 & 13.3 & $2,543.00$ & 733 & 65 \\
Santa Cruz & 24.10 & 15.3 & $2,231.00$ & 1,085 & 49 \\
Buena Vista & 24.10 & 14.6 & $2,182.00$ & 2,101 & 55 \\
Sacta & 25.10 & 14.9 & $2,090.00$ & 2,782 & 52 \\
Villa Tunari & 24.90 & 14.4 & $1,956.00$ & 3,710 & 53 \\
\hline
\end{tabular}


to 3:30 p.m., we patrolled these lines, netting all bees hovering at a trap. The bees were killed with acetic aether or formol. Specimens were dried on silica gel, put into paper bags for transport, and later pinned for identification. The species were identified following Dressler (1982a, b, c; 1985), Kimsey (1982), BonillaGómez and Nates-Parra (1992), Bembé (2004), Roubik (2004), Anjos-Silva and Rebêlo (2006), Oliveira (2006), and Nemésio and Silveira (2009).

\subsection{Data analyses}

In the analyses we included all species of which more than 20 individuals had been collected. To test whether the number of aromatic substances used per species was related to the number of individuals per species, we conducted a linear regression. We used $g$ tests to assess whether these species changed their aromatic preference between the rainy and the dry seasons. Further, we conducted paired $t$ tests to assess whether one group of species (whole dataset; species with changes in their aromatic preferences between seasons) were more common during one season. To find out whether the number of aromatic substances used by the species that changed their aromatic preference between seasons was higher than the number of aromatic substances used by the other species, we conducted a $t$ test. With another paired $t$ test, we tested whether the number of aromatic substances that attracted the individual species differed between seasons. We tested this for the whole dataset and for the species that showed aromatic preferences between seasons. Then, by linear regression analyses, we related climatic factors (temperature and precipitation seasonality) to the proportion of species per site that showed significantly different preferences between seasons. The analyses were conducted in R (R Development Core Team 2007).

\section{RESULTS}

In total we collected 1,207 individuals of orchid bees belonging to 43 species (Supplementary Appendix 1). Of these, 11 species were recorded with more than 20 individuals and were included in further analyses (Table II). The number of aromatic substances that the individual species were attracted to ranged from five to ten with a mean of 8.3. The number of aromatic substances used per species was not significantly related to the individual number per species $(R=$ $0.65, P=0.063)$. Six species showed significant changes in their aromatic preferences between seasons. There was no seasonal shift in the species richness of orchid bees in the whole dataset (paired $t$ test: $t=-0.75, P=0.472$ ) nor among the species that showed changes in their aromatic preferences between seasons $(t=-0.79$,

Table II. Total number of aromatic substances (in brackets) used per species and number of orchid bee individuals per site.

\begin{tabular}{lccccc}
\hline & Río Seco & Santa Cruz & Buena Vista & Sacta & Villa Tunari \\
\hline Euglossa amazonica* $(10)$ & 0 & 10 & 52 & 64 & 33 \\
Euglossa chalybeata (5) & 0 & 0 & 2 & 7 & 17 \\
Euglossa cordata (10) & 0 & 76 & 20 & 2 & 2 \\
Euglossa despecta* (7) & 4 & 4 & 30 & 26 & 19 \\
Euglossa fimbriata* (10) & 30 & 47 & 9 & 1 & 0 \\
Euglossa imperialis (5) & 0 & 0 & 26 & 21 & 3 \\
Euglossa magnipes $(9)$ & 0 & 4 & 29 & 18 & 16 \\
Euglossa mixta $(10)$ & 0 & 3 & 77 & 53 & 35 \\
Euglossa modestior* (6) & 0 & 1 & 3 & 47 & 56 \\
Euglossa orellana* (10) & 0 & 0 & 22 & 66 & 104 \\
Eulaema nigrita* $(9)$ & 0 & 8 & 9 & 5 & 0 \\
\hline
\end{tabular}

$* P \leq 0.05$, species with seasonally changing aromatic preferences 
$P=0.467)$. The number of attractants used by the species with changes in their aromatic preferences between seasons was not significantly higher than that used by the other species ( $t$ test, $t=0.66$, $P=0.525)$. We did not find significant differences for the number of aromatic substances that attracted the individual species between seasons for the whole dataset (paired $t$ test: $t=-2.17$, $P=0.056$ ) nor for the species that showed changes in their aromatic preferences between seasons $(t=-1.88, P=0.119)$. When we related the proportion of species that did not show seasonal changes in their aromatic preferences per site to environmental characters, we found that temperature seasonality was the most powerful explanatory variable (Table III, Figure 1).

\section{DISCUSSION}

At all study sites, we found orchid bee species that changed their aromatic preferences between seasons. Importantly, the proportion of these species in the local assemblages increased from tropical evergreen rainforests to subtropical, deciduous dry forests. This pattern was best explained by increasing climatic seasonality, especially regarding temperatures.

Orchid bees are known to visit a wide array of plant species for nectar supply and to collect aromatic substances, although some species are very specific in the aromatic substances that they collect (Ackerman 1989). In Peru, Pearson and

Table III. Strength of relation ( $R$ values) for regression analysis of the proportion (percent) of species without aromatic preferences per site against environmental parameters.

\begin{tabular}{lc}
\hline & $\begin{array}{c}\text { \% Species without } \\
\text { aromatic preferences }\end{array}$ \\
\hline Mean temperature $\left({ }^{\circ} \mathrm{C}\right)$ & -0.40 \\
Min. temperature $\left({ }^{\circ} \mathrm{C}\right)$ & -0.73 \\
Temperature seasonality & $0.97 *$ \\
Mean precipitation $(\mathrm{mm})$ & -0.82 \\
Precipitation seasonality & 0.83 \\
\hline
\end{tabular}

$* P \leq 0.01$

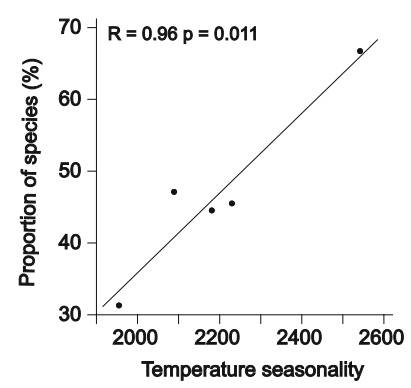

Figure 1. Proportion of species without aromatic preferences per site against temperature seasonality (extracted from WorldClim, Hijmans et al. 2005) in the different study sites.

Dressler (1985) found that those specialized euglossine bee species that are only attracted by a few substances did not show changes in their aromatic preferences between seasons, whereas some of the generalistic species, using a large number of aromatic substances, differed in their preferences between seasons (see also Ackerman 1989). In our study, we found the same tendency, although the results were not quite significant. Probably, we mainly found generalists and only a few specialists, as suggested by the relatively high number of aromatic substances that the species were attracted to. In accordance to this, we found that the proportion of species that changed their aromatic preferences between seasons increased with increasing climatic seasonality towards the south. Unsurprisingly, it thus appears that only generalistic species using a wide range of aromatic substances are able show shifts in their preferences between seasons. However, not all generalistic species do so. We can conceive two non-exclusive interpretations of the causes of shifting aromatic preferences between seasons among orchid bees.

First, in extension to previous studies mainly conducted in climatically largely aseasonal evergreen rainforests (Pearson and Dressler 1985; Ackerman 1989), we were able to link the variation of aromatic preferences between seasons to climatic seasonality. It is likely that climatic seasonality mainly affects the orchid bees via the turnover of the aromatic substances provided by the plants. Plant phenology is well 
known to be strongly determined by environmental factors, and plant species in climatically more seasonal sites tend to synchronise their phenology more strongly than in climatically non-seasonal sites (Günter et al. 2008). Furthermore, drier habitats are generally less species rich in plants than humid ones, also with respect to orchids in our study region (Linares-Palomino et al. 2009), which are the major source of aromatic substances for the bees (Whitten and Williams 1991). Therefore, in more seasonal habitats, orchid bees have to change their aromatic preferences between seasons because some aromatic substances are not available during parts of the year. The learning effect, as reported by Eltz et al. (2005), is not likely to explain our pattern of seasonal preference changes because we did not visit our study sites during the dry season in the same order as in the rainy season. The intervals between the visits varied between 3 and 5 months. Thus, bee populations at the different sites had different absolute ages, which strongly influence learning behaviour. It is much more likely that the change in odour preferences is a reaction to a changed availability of substances. Indeed, Eltz et al. (2005) and Ramírez et al. (2010b) showed not only that euglossine species have a speciesspecific odour composition but also that the composition of collected substances can change when only a subset of substances is available, for example on a small island or in areas where orchid bees were introduced. Accordingly, the shifts of aromatic preferences between seasons among orchid bee species at the southern sites may mainly be an opportunistic reaction to the seasonal turnover of a limited number of aromatic substances provided by the plants.

Second, it is striking that the species found in our study that show preferences of aromatic substances between seasons are not randomly distributed across the phylogenetic tree of orchid bees. Rather, most species belong to Euglossa subgenus Euglossa, which evolved and diversified rather recently (Ramírez et al. 2010a), with a single additional species belonging to Eulaema. No species from another clade occurred in the two climatically most seasonal study sites. It is therefore tempting to speculate that the generalistic and opportunistic behaviour, which also occurs in tropical sites, is a phylogenetically restricted pre-adaptation to seasonally shifting environmental conditions and enabled these species to colonize climatically strongly seasonal habitats. To support this statement, it would be necessary to show in a behavioural experiment that species from other groups are unable to react in the same flexible manner to chances of aromatic substance availability. Another approach might be to sample the content of the pockets of the hind tibia of different species in different seasons and check whether the composition is more variable in species belonging to the subgenus Euglossa compared to species of other subgenera in the same habitat.

\section{ACKNOWLEDGEMENTS}

We thank Y. Gareca, C. Hamel, S.K. Herzog, S. Reichle, V. Sandoval, and J.Q. Vidoz for their support and advice during fieldwork. We are grateful to the Botanical Garden in Santa Cruz; the University of Cochabamba, Prometa; the municipal governments of Villa Tunari and Río Seco; and R. Clarke Gemuseus for the permission to work on their land. Furthermore, we thank B. Bembé and G. Gerlach for technical advice, C. Rasmussen and B. Bembé for the support and advice in identifying the specimens, and $\mathrm{M}$. Schwerdtfeger for the baiting agents. Funding was provided by the Konrad-Adenauer-Stiftung and the DFG (Deutsche Forschungsgemeinschaft).

Changements saisonniers dans les préférences olfactives des mâles d'abeilles Euglossine (Hymenoptera: Apidae) et leur implication écologique.

gradient climatique / précipitations / température / distribution / espèce généraliste

Jahreszeitliche Änderungen der Duftpräferenzen männlicher Prachtbienen (Euglossini, Hymenoptera: Apidae) und ihrer ökologischen Auswirkungen.

Klimatischer Gradient/ Niederschlag/ Temperatur/ Ausbreitung/ Generalist 


\section{REFERENCES}

Ackerman, D. (1983) Diversity and seasonality of the male euglossine bees (Hymenoptera: Apidae) in central Panamá. Ecology 64, 274-283

Ackerman, D. (1989) Geographic and seasonal variation in fragrance choices and preferences of male euglossine bees. Biotropica 21, 340-347

Anjos-Silva, E.J., Rebêlo, J.M.M. (2006) A new species of Exaerete Hoffmannsegg (Hymenoptera: Apidae: Euglossini) from Brazil. Zootaxa 1105, 27-35

Bembé B. (2004) Revision der Euglossa cordata-Gruppe und Untersuchung zur Funktionsmorphologie und Faunistik der Euglossini. PhD Thesis, LudwigMaximilian-Universität München, Germany

Bonilla-Gómez, M.A., Nates-Parra, G. (1992) Abejas euglossinas de Colombia (Hymenoptera: Apidae) I. Claves ilustradas. Caldasia 17, 149-172

Dressler, R.L. (1982a) New species of Euglossa II. (Hymenoptera: Apidae). Rev. Biol. Trop. 30, 121129

Dressler, R.L. (1982b) New species of Euglossa III. The bursigera species group (Hymenoptera: Apidae). Rev. Biol. Trop. 30, 131-140

Dressler, R.L. (1982c) New species of Euglossa IV. The cordata and purpurea species groups (Hymenoptera: Apidae). Rev. Biol. Trop. 30, 141-150

Dressler, R.L. (1985) Euglossine bees (Hymenoptera: Apidae) of the Tambopata reserved zone, Madre de Dios. Perú. Rev. Peruana Entomol. 27, 75-79

Eltz, T., Whitten, W.M., Roubik, D.W., Linsenmair, K.E. (1999) Fragrance collection, storage, and accumulation by individual male orchid bees. J. Chem. Ecol. 25, 157-175

Eltz, T., Roubik, D.W., Lunau, K. (2005) Experiencedependent choices ensure species-specific fragrance accumulation in male orchid bees. Behav. Ecol. Sociobiol. 59, 146-156

Günter, S., Stimm, B., Cabrera, M., Diaz, M.L., Lojan, M., Ordoñez, E., Richter, M., Weber, M. (2008) Tree phenology in montane forests of southern Ecuador can be explained by precipitation, radiation and photoperiodic control. J. Trop. Ecol. 24, 247-258

Hijmans, R.J., Cameron, S.E., Parra, J.L., Jones, P.G., Jarvis, A. (2005) Very high resolution interpolated climate surfaces for global land areas. Intern. J. Climatol. 25, 1965-1978

Kimsey, L.S. (1982) Systematics of bees of the genus Eufriesea (Hymenoptera, Apidae). Entomology: 95. University of California Press, Berkeley

Linares-Palomino, R., Cardona, V., Hennig, E.I., Hensen, I., Hoffmann, D., Lendzion, J., Soto, D., Herzog, S.K., Kessler, M. (2009) Non-woody life form contribution to vascular plant species richness in a tropical American forest. Plant Ecol. 201, 87-99

Nemésio, A., Silveira, F.A. (2009) Orchid bees (Hymenoptera: Apidae) of the Brazilian Atlantic forest. Zootaxa 2041, 1-242

Oliveira, M.L. (2006) Três novas espécies de abelhas da Amazônia pertencentes ao gênero Eulaema (Hymenoptera: Apidae: Euglossini). Acta Amazonica 36, 121-128

Pearson, D.L., Dressler, R.L. (1985) Two-year study of male orchid bee (Hymenoptera: Apidae: Euglossini) attraction to chemical baits in lowland south-eastern Peru. J. Trop. Ecol. 1, 37-54

Ramírez, S.R., Roubik, D.W., Skov, C., Pierce, N.E. (2010a) Phylogeny, diversification patterns and historical biogeography of euglossine orchid bees (Hymenoptera: Apidae). Biol. J. Lin. Soc. 100, 552-572

Ramírez, S.R., Eltz, T., Fritsch, F., Pemberton, R., Pringle, E.G., Tsutsui, N.D. (2010b) Intraspecific geographic variation of frangrance acquired by orchid bees in native and introduced populations. J. Chem. Ecol. 36, 873-884

R Development Core Team, (2007) R (data analysis software system), version 2.11.0, R Foundation for Statistical Computing, Vienna

Roubik, D.W. (2004) Sibling species of Glossuropoda in the Amazon region (Hymenoptera: Apidae: Euglossini). J. Kansas Entomol. Soc. 77, 235253

Steyskal, G.C. (1977) History and use of the McPhail trap. Fla Entomol. 60, 11-16

Whitten, W.M., Williams, N.H. (1991) A new species and nomenclatural changes in Gongora section Acropera (Orchidaceae). Lindleyana 6, 109-112

Zimmerman, J.K., Madrinan, S. (1988) Age structure of male Euglossa imperialis (Hymenoptera: Apidae: Euglossini) at nectar and chemical sources. J. Trop. Ecol. 4, 303-306 